\title{
Anderson Heteropolymolybdates Cluster Loaded on Zeolite Materials: Preparation and Characterization
}

\author{
Mohamed S. Thabet ${ }^{1,2}$ \\ ${ }^{1}$ Department of Chemistry, Faculty of Science, Al-Azhar University, Nasr City, Cairo, Egypt \\ ${ }^{2}$ Department of Chemistry, Faculty of Science, Jazan University, Jazan, KSA \\ Email: thabet1972@yahoo.com
}

How to cite this paper: Thabet, M.S. (2019) Anderson Heteropolymolybdates Cluster Loaded on Zeolite Materials: Preparation and Characterization. Journal of Encapsulation and Adsorption Sciences, 9, 1-12. https://doi.org/10.4236/jeas.2019.91001

Received: January 16, 2019

Accepted: March 5, 2019

Published: March 8, 2019

Copyright () 2019 by author(s) and Scientific Research Publishing Inc. This work is licensed under the Creative Commons Attribution International License (CC BY 4.0).

http://creativecommons.org/licenses/by/4.0/

\begin{abstract}
Polyoxometalate $(\mathrm{POM})$ catalysts with different trivalent hetero ions $\left(\mathrm{M}^{\mathrm{nt}}=\right.$ $\mathrm{Fe}^{3+}, \mathrm{Al}^{3+}$, and $\mathrm{Cr}^{3+}$ ) were prepared by incipient wetness impregnation method and supported on different zeolites namely, NaY, ZSM- 5 and Mordenite. The intended catalysts samples were distinguished by X-ray diffraction, FTIR and surface texture measurements. The data given disintegration in the crystallinity of zeolite structure, enlarge in particle size and new phases of metal oxides $\mathrm{Al}_{2}\left(\mathrm{MoO}_{4}\right)_{3}$ and $\mathrm{Fe}_{2}\left(\mathrm{MoO}_{4}\right)_{3}$ were exposed by XRD and FTIR techniques. These phases caused widening of pores of the employed zeolites and change of the surface texture. The physical changes indicate the considerable interaction of polyoxomolybdate with the zeolite structure. The assessment of the catalytic activity was thorough by applied the photocatalytic degradation of direct blue 1 dye (DB1) in existence of $\mathrm{H}_{2} \mathrm{O}_{2}$ as a green oxidant. The catalytic activity of $\mathrm{M}^{\mathrm{n}+}$ Mo-ZSM- 5 sample is higher than that of $\mathrm{M}^{\mathrm{n}+} \mathrm{Mo}-\mathrm{Y}$ or $\mathrm{M}^{\mathrm{nt}}$ Mo-Mord.
\end{abstract}

\section{Keywords}

Polyoxometalate, Zeolites, Anderson, Cluster

\section{Introduction}

Polyoxometalates (POMs) is one of the most remarkable chemicals and physical properties materials, and because its structure can be considered as a new multifunctional material, it can be used in different applications [1] [2] [3] [4]. Polyoxometalates has a huge function group of oligomeric cluster anions, which are used in catalyst design because of their acidity and capability of oxidation [5]. Until now the ultimate serious application of POMs is the scope of catalyst, 
specially the selective oxidation of industrial materials and products [6] [7]. Newly, POMs have also been utilized as environment catalysts for the decay of organic pollutants [8] [9] [10]. The structure of POMs and additional elements with different coordination number surrounding by $\mathrm{MoO}_{6}$ has oxygen atoms making oxyanions structure with high reactivity and is called Anderson structure, and the most important application of POM anions is a solution of different environmental problems due to the reactivity of the free hydroxyl radicals, $\mathrm{OH}^{-}$[10] [11]. Thus, transition metal ions have been used to promote advantage oxidation process and help in visible light adsorption [12]. Hydrothermal oxidation processes (HOP) have been inclusively studied for their application to a diversity of rebellious pollutants and actual wastewater [13]. A free radical chain auto-oxidation process was explained based on the rapid oxidation of aromatic substances and conversion to simple molecular weight or formulation of different type of radicals accountable for the autocatalytic decomposition of the original substrate [14] [15].

Zeolite has been inspected as potential supports for the hybrid photocatalytic system [16] [17]. Due to the various distinguishing advantages of zeolite such as cages, channels and electrons transfer that could facilitate the adsorption of organic species as preliminary stage for the photocatalytic degradation, transition metals modified zeolite can be used for the removal of organic compound. The transition metal combination may be probably behaving as an electron acceptor and thus supports a critical role in incorporation with the zeolite framework to make a possible retard in the recombination process [18].

In current work, I have attempted to join the above properties of zeolites in a suitable manner to prepare novel catalytic materials. This involves a combination of POMs loaded transition metal supported into different zeolites. This appears to have resulted in synergistic enhancement of the catalytic activity for the degradation of direct blue 1 dye as a test reaction. The behavior of the investigated diazo dyes is likely to be that of their mono-azo counterparts.

\section{Experimental}

\subsection{Preparation of $\mathrm{M}^{3+} /$ Anderson Phase}

The Anderson phase with the general formula $\left(\mathrm{NH}_{4}\right)_{2}\left[\mathrm{X}(\mathrm{III}) \mathrm{Mo}_{6} \mathrm{O}_{24} \mathrm{H}_{6}\right] 7 \mathrm{H}_{2} \mathrm{O}$, $\left(\mathrm{X}=\mathrm{Cr}^{3+}, \mathrm{Al}^{3+}\right.$, or $\mathrm{Fe}^{3+}$ ) were gained by precipitation method from an aqueous solution as described elsewhere [19]. Briefly, an aqueous solution of metal sulphates $\left(3.1 \mathrm{mmol}\right.$ ) in $20 \mathrm{ml} \mathrm{H} \mathrm{H}_{2} \mathrm{O}$ is added to a boiling solution of ammonium molybdate ( $4.2 \mathrm{mmol}$ ) dissolved in $80 \mathrm{ml} \mathrm{H}_{2} \mathrm{O}$. Furthermore, evaporation this solution until a precipitate is completely formed, filtering the hot solution and cooling. The acquired past was recrystallized twice with water to obtain purified solids.

\subsection{Preparation of $\mathrm{M}^{3+} /$ Anderson Phase Supported on Different Zeolites}

The Anderson phase containing trivalent cations $\left(\mathrm{Al}^{3+}, \mathrm{Fe}^{3+}\right.$, and $\left.\mathrm{Cr}^{3+}\right)$ loaded on NaY, ZSM-5 and Mordenite zeolites were prepared by incipient wetness im- 
pregnation method in which a known weight of zeolite powder was immersed in a solution of the Anderson molybdo-polyanions. The mixture was kept under constant stirring for 5 hours at $80^{\circ} \mathrm{C}$. The samples obtained was dried at $120^{\circ} \mathrm{C}$ then calcined for $3 \mathrm{~h}$ at $400^{\circ} \mathrm{C}$, then the samples will be referred as $\mathrm{xM}^{3+} \mathrm{Mo}-\mathrm{Z}$, where $\mathrm{x}, \mathrm{M}^{3+}$, and $\mathrm{Z}$ are donated to the Anderson ratio (5\%), the ion of the heteroatom in Anderson structure and zeolite type respectively.

\subsection{Characterization of $\mathrm{M}^{3+} /$ Anderson Phase Supported on Different Zeolites}

Crystallinity and new phases were determined by X-ray diffraction using instrument diffractometer (DMX 111-VC, Rigaku Denki Co.) with CuK radiation. The powder diffractograms of various samples were recorded from $2 \theta=5^{\circ}$ to $60^{\circ}$ with a scanning rate of $4^{\circ} \mathrm{min}^{-1}$. The Scherrer equation [20] employing to calculate the mean particle size, surface characteristics of various zeolitic solids were determined from $\mathrm{N}_{2}$ adsorption isotherm conducted at $-196^{\circ} \mathrm{C}$ under reduced pressure as low as $10^{-5}$ torr by conventional volumetric apparatus. Out gassed the sample at $200^{\circ} \mathrm{C}$ for $3 \mathrm{hrs}$ to remove moisture. The specific surface area $\left(S_{\mathrm{BET}}\right)$ were estimated using the BET method [21], while the statistical surface area $\left(S_{t}\right)$, micropores surface area $\left(S_{\text {mic }} \cdot\right)$, wide pore surface $\left(S_{\text {wide }}\right)$, total pore volume $\left(\mathrm{V}_{\mathrm{p}}\right)$ and mean pore radius $(\bar{r})$ were obtained from the t-plot method which developed by de Boer et al. [22]. The Fourier Transform Infrared (FTIR) spectra were measured using a Bruker (Vector 22), single beam spectrometer with a resolution of $2 \mathrm{~cm}^{-1}$, make a tablet by grinding the samples with $\mathrm{KBr}(1$ : 100 ratio), the recorded spectral changes were revealed in two regions at 4000 3000 and $1200-400 \mathrm{~cm}^{-1}$. Particle size was evaluated by a particle size analyzer (LB-500 HORIBA, Dynamic Light Scattering). The samples were stirred in $90 \mathrm{ml}$ of distilled water and $10 \mathrm{ml}$ of sodium hexametaphosphate for $10 \mathrm{~min}$., then with ultrasonic for 10-minute insert $3 \mathrm{ml}$ of sample in the unit cell to be measured. The photo reactivity experimental was executed in a cylindrical Pyrex glass reactor containing $0.1 \mathrm{~g}$ of catalyst and $100 \mathrm{ml}$ of a solution of direct blue 1 dye. The concentration of the dye was $50 \mathrm{ppm}$. A $6 \mathrm{~W}$ medium pressure Hg lamp (256 nm) was used. The oxidant $\mathrm{H}_{2} \mathrm{O}_{2}$ concentration $(61 \mathrm{mmol}$ ) was fixed throughout the experimental test and performed at $25^{\circ} \mathrm{C}$, withdrawn the sample at time intervals for analysis by (HASCO V-570-unit, serial No. 29635) UV-Vis spectrophotometer over the 190 - $800 \mathrm{~nm}$ range. The decolonization was determined at the maximum wavelength at $618 \mathrm{~nm}$, removal efficiency percentage of DB1 dye was calculated by applying the following equation

$$
\text { Efficiency\% }=\frac{\left(C-C_{0}\right)}{C_{0}} \times 100,
$$

where $C_{\mathrm{o}}$ and $C$ are the original and retained DB1 dye in solution, respectively.

\section{Results and Discussion}

The XRD patterns of CrMo-, FeMo- and AlMo-Y samples show that the fau- 
jasite structure was kept intact but a decrease in the intensity of its diffraction lines was observed Figure 1, which might indicate that molybdenum species were introduced and interacted with the internal framework of $\mathrm{NaY}$ zeolite. This result was evidenced by the existence of $\mathrm{M}_{2}\left(\mathrm{MoO}_{4}\right)_{3}$ composite (where $\mathrm{M}=\mathrm{Cr}^{3+}$, $\mathrm{Fe}^{3+}$, and $\mathrm{Al}^{3+}$ ) at $2 \theta=23.4^{\circ}$ which appeared in all prepared samples except CrMo-Y, another phase was detected for $\mathrm{MoO}_{3}$ at $2 \theta=12.6^{\circ}, 22.8^{\circ}, 25.5^{\circ}$ and $27.3^{\circ}$. The least stability regarding the intensity of zeolite characteristic peaks was observed in FeMo-Y sample. The sample contains $\mathrm{Cr}^{3+}$ showed neither new phases nor crystallinity changes indicating that the NaY zeolite had the highest stability in the presence of $\mathrm{Cr}^{3+}$ containing heteropolyacids. The data of particle size, crystal size, crystallinity and cell volume of $\mathrm{M}^{3+} \mathrm{Mo}-\mathrm{Y}$ catalysts are recorded in Table 1. The crystallinity decreased especially in FeMo-Y where it goes down to $21 \%$ with respect to the parent $\mathrm{NaY}$ zeolite whereas it did not change in a sample containing $\mathrm{Cr}^{3+}$. Once more, this indicated that zeolite preserves its structure in the state of $\mathrm{Cr}$-containing catalyst more than that of Fe-containing one. Whereas, the cell volume, Table 1 , decreases in whole samples but slightly increased in case of Al-containing material this may indicate that decrease of the extent of dealumination attributed to the addition of $\mathrm{Al}^{3+}$ ions.

The X-ray diffraction pattern of $\mathrm{M}^{3+}$ Mo-ZSM-5 catalysts and parent zeolite are shown in Figure 1. The peak intensity of $\mathrm{M}^{3+} \mathrm{Mo}-\mathrm{ZSM}-5$ decreased even out of the crystal structure of ZSM-5 was kept unaffected after loading of $\mathrm{M}^{3+} \mathrm{Mo}$-Anderson. Such loading brought about the appearance of $\mathrm{MoO}_{3}$ phase at $2 \theta=23.1^{\circ}, 27.2^{\circ}$ and $33.7^{\circ}$. Metal molybdate was detected on the surface of the Fe-containing sample only in view of the fact that the characteristic line of $\mathrm{Fe}_{2}\left(\mathrm{MoO}_{4}\right)_{3}$ phase at $39.0^{\circ}$ has been detected [PDF \# 33-0661]. In addition, it appears together in the
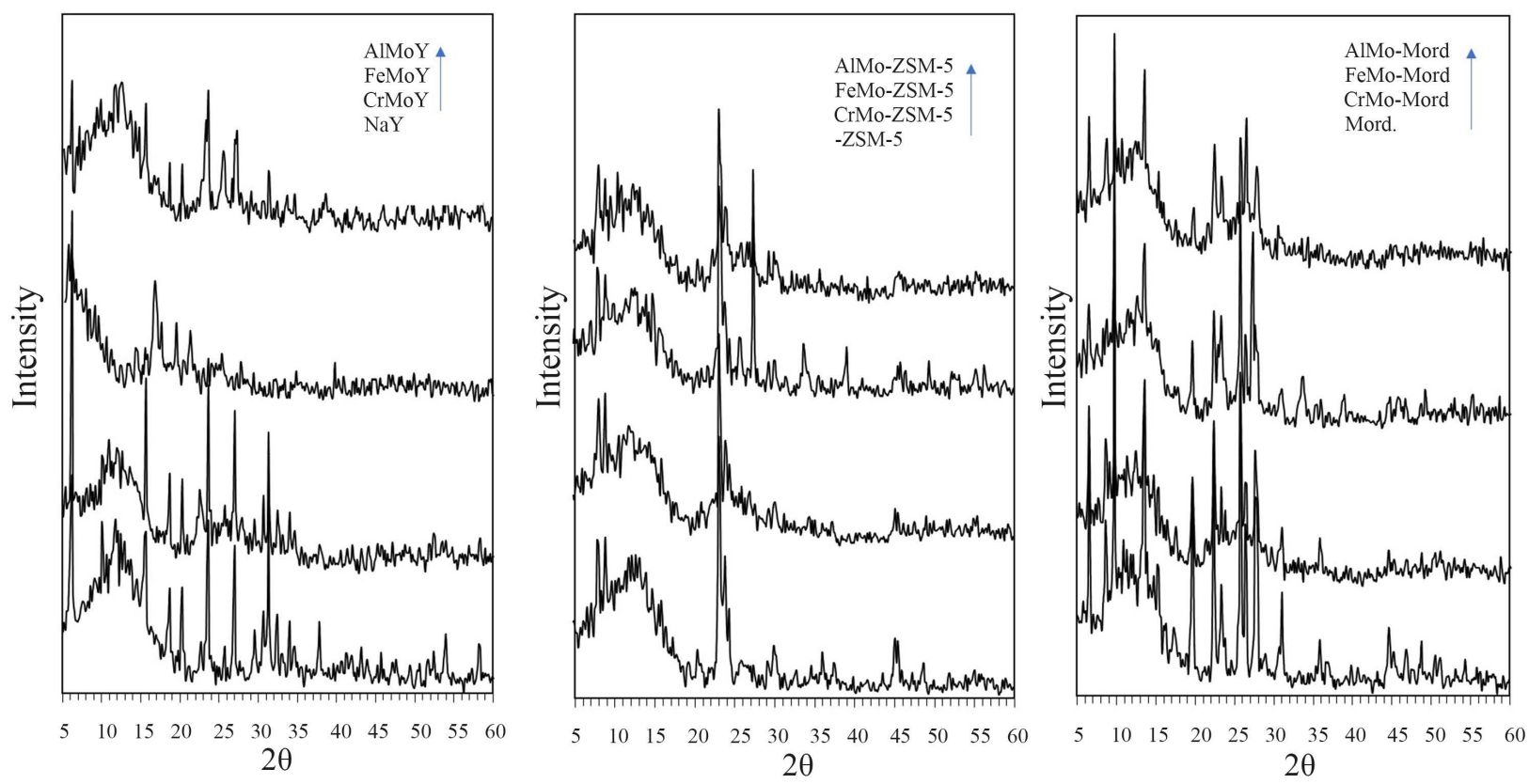

Figure 1. XRD patterns of parent zeolites and $\mathrm{M}^{3+} \mathrm{Mo-zeolite} \mathrm{solids} \mathrm{with} \mathrm{different} \mathrm{M}^{3+} \mathrm{Mo}$-Anderson. 
Table 1. Variation of cell parameters after supporting $\mathrm{M}^{3+} \mathrm{Mo}-$ Anderson on NaY zeolite.

\begin{tabular}{cccccc}
\hline Sample & $\begin{array}{c}\text { Crystal Size, } \\
\mathrm{nm}\end{array}$ & $\begin{array}{c}\text { Particle Size, } \\
\mu \mathrm{m}\end{array}$ & $\begin{array}{c}\text { Crystallinity, } \\
\%\end{array}$ & $\begin{array}{c}\text { Cell Constant, } \\
(\AA)\end{array}$ & $\begin{array}{c}\text { Cell Volume, } \\
(\AA)^{3}\end{array}$ \\
\hline $\mathrm{NaY}$ & 64.5 & 3.73 & 100 & 24.52 & 14,749 \\
$\mathrm{CrMo}-\mathrm{Y}$ & 126 & 3.93 & 100 & 24.43 & 14,389 \\
FeMo-Y & 127.2 & 3.85 & 21.3 & 24.42 & 14,562 \\
AlMo-Y & 64.5 & 3.93 & 46.1 & 24.58 & 14,849 \\
\hline
\end{tabular}

same position of $\mathrm{MoO}_{3}$ lines at $2 \theta=23.1^{\circ}, 27.2^{\circ}$ and $33.7^{\circ}$. The evaluation of the spectra of $\mathrm{M}^{3+} \mathrm{Mo}-\mathrm{Y}$ and $\mathrm{M}^{3+} \mathrm{ZSM}-5$ informs that ZSM-5 is more stable than NaY when being used as a support for $\mathrm{M}^{3+} \mathrm{Mo}-\mathrm{HPA}$, that may be referred to the lower alumina content in ZSM-5 than NaY. The data recorded in Table 2 point to the enlargement occurring in the particle size and crystal size. In the same manner, it tells about the decrease in crystallinity and cell parameters of the crystal structure after supporting $\mathrm{M}^{3+} \mathrm{Mo}$ on ZSM-5 zeolite. On the other hand, the X-ray diffraction pattern of $\mathrm{M}^{3+} \mathrm{Mo}-\mathrm{Mordenite}$ and parent mordenite catalyst are exhibited in Figure 1. The crystal structure of mordenite was kept unchanged but a decrease in its peak intensity was noticed after the impregnation with $\mathrm{M}^{3+} \mathrm{Mo}$. No new peaks were observed expect of $\mathrm{Fe}_{2}\left(\mathrm{MoO}_{4}\right)_{3}\left(2 \theta=22.8^{\circ}, 27.3^{\circ}\right.$ and $33.7^{\circ}$ and $39.0^{\circ}$ ) in case of $\mathrm{Fe}$-Containing sample. The other sample displayed a decrease in crystallinity accompanied by an increase in particle size and crystal size, Table 2, Figure 1. It is clear that $\mathrm{MoO}_{3}$ has not been observed in the case of $\mathrm{M}^{3+} \mathrm{Mo}$-mordenite. This may be due to the facile dispersion of the $\mathrm{M}^{3+}$ Mo moieties on the mordenite surface.

The surface characteristics of $\mathrm{M}^{3+} \mathrm{Mo}$-Anderson supported on different zeolite materials were conducted via $\mathrm{N}_{2}$ adsorption isotherms (Table 3). All the obtained isotherms belong to type II approbate to Brunauer classification [23]. Table 3, Figure 2 revealed that: the values of $S_{B E T}$ and $S t$ are closed to each other for all samples investigated, indicates the correct choice of the standard $t$-curves. The computed values of mean pore radii of samples showed higher values than those of the parent zeolites. For instance, $\bar{r}$ of $\mathrm{NaY}$ is $16.3 \AA$ whereas those of supported samples ranged between 19 - $23 \AA$ similarly $\bar{r}$ of ZSM-5 zeolite is equal to $18.7 \AA$ and those of supported materials have a value of $22 \AA$. These higher value of $\bar{r}$ may be due to the imposed position of metal oxides $\left(\mathrm{M}_{2} \mathrm{O}_{3}\right.$, where $\mathrm{M}$ $\left.=\mathrm{Mo}^{6+}, \mathrm{Al}^{3+}, \mathrm{Cr}^{3+}, \mathrm{Fe}^{3+}\right)$ or new phases such as $\mathrm{Al}_{2}\left(\mathrm{MoO}_{4}\right)_{3}, \mathrm{Fe}\left(\mathrm{MoO}_{4}\right)_{3}$ which were detected by XRD and FTIR techniques, into the pores of zeolites leading to an effecting pore widening. The $V_{1-t}$ plots of samples, Figure 3 indicates mainly the existence of micropores (downward deviation) with a small margin of wide pores that indicated by deviations in the $t$ rang of $6-8 \AA$. The Fe-Y sample measured the minimum value of $\mathrm{Vp}$ and medium $\bar{r}$ value (19.2 $\AA$ ) referring to the forced location of Fe species in pores of this particular sample leading to slight pore widening this reflects the presence of major of Fe cations as oxides outside the pores of the zeolite. 
Table 2. Variation of cell parameters after supporting $\mathrm{M}^{3+}$ Mo-Anderson on ZSM-5 and mordenite zeolite.

\begin{tabular}{|c|c|c|c|c|c|c|c|}
\hline \multirow{2}{*}{ Sample } & \multirow{2}{*}{$\begin{array}{l}\text { Crystal } \\
\text { Size, nm }\end{array}$} & \multirow{2}{*}{$\begin{array}{l}\text { Particle } \\
\text { Size, } \mu \mathrm{m}\end{array}$} & \multirow{2}{*}{$\begin{array}{c}\text { Crystallinity, } \\
\%\end{array}$} & \multicolumn{3}{|c|}{ Cell parameters, $(\AA)$} & \multirow{2}{*}{$\begin{array}{c}\text { Cell } \\
\text { Volume, } \\
(\AA)^{3}\end{array}$} \\
\hline & & & & $\mathrm{a}$ & $\mathrm{b}$ & $\mathrm{c}$ & \\
\hline ZSM-5 & 67.2 & 3.94 & 100 & 19.76 & 20.02 & 13.52 & 5348 \\
\hline CrMo-ZSM-5 & 88.3 & 4.01 & 82.5 & 19.90 & 19.52 & 13.45 & 5224.6 \\
\hline FeMo-ZSM-5 & 127.2 & 4.15 & 74.5 & 19.94 & 20.01 & 13.43 & 5358.6 \\
\hline AlMo-ZSM-5 & 135.2 & 4.06 & 62.0 & 19.90 & 19.99 & 13.42 & 5338.4 \\
\hline Mordenite & 76.9 & 4.31 & 100 & 18.14 & 20.32 & 7.46 & 2749.7 \\
\hline CrMo-Mord. & 126.0 & 4.61 & 58 & 18.09 & 20.45 & 7.47 & 2763.4 \\
\hline FeMo-Mord. & 102.0 & 4.01 & 46.2 & 18.14 & 19.72 & 7.49 & 2679.3 \\
\hline AlMo-Mord. & 89.7 & 4.88 & 38.2 & 18.02 & 20.27 & 7.45 & 2721.2 \\
\hline
\end{tabular}

Table 3. Surface characteristic of different investigated $\mathrm{M}^{3+} \mathrm{Mo}-$ Anderson supported on different zeolites, preheated at $300{ }^{\circ} \mathrm{C}$ under a reduced pressure of $10^{-5}$ torr.

\begin{tabular}{|c|c|c|c|c|c|c|c|c|c|c|}
\hline Sample & $\begin{array}{c}\mathrm{S}_{\mathrm{BET}} \\
\left(\mathrm{m}^{2} / \mathrm{g}\right)\end{array}$ & $\begin{array}{c}\mathrm{S}_{\mathrm{t}} \\
\left(\mathrm{m}^{2} / \mathrm{g}\right)\end{array}$ & $\begin{array}{c}V_{p}^{\text {total }} \\
\left(\mathrm{cm}^{3} / \mathrm{g}\right)\end{array}$ & $\begin{array}{c}V_{p}^{\mu} \\
\left(\mathrm{cm}^{3} / \mathrm{g}\right)\end{array}$ & $\begin{array}{c}V_{p}^{\text {wid }} \\
\left(\mathrm{cm}^{3} / \mathrm{g}\right)\end{array}$ & $\begin{array}{c}S^{\mathrm{ext}} \\
\left(\mathrm{m}^{2} / \mathrm{g}\right)\end{array}$ & $\begin{array}{c}\mathrm{S}^{\mu} \\
\left(\mathrm{m}^{2} / \mathrm{g}\right)\end{array}$ & $\begin{array}{c}\mathrm{S}^{\text {wid }} \\
\left(\mathrm{m}^{2} / \mathrm{g}\right)\end{array}$ & $\begin{array}{c}\boldsymbol{r}^{-} \\
(\AA)\end{array}$ & $\mathrm{C}$ \\
\hline $\mathrm{NaY}$ & 908 & 825 & 0.668 & 0.592 & 0.076 & 50.50 & 226.7 & 681.2 & 16.30 & 481 \\
\hline AlMo-Y & 428 & 475 & 0.433 & 0.404 & 0.029 & 19.74 & 105.6 & 322.8 & 23.58 & 17 \\
\hline CrMo-Y & 491 & 447 & 0.454 & 0.410 & 0.047 & 32.43 & 107 & 384.0 & 20.7 & 89 \\
\hline FeMo-Y & 441 & 424 & 0.381 & 0.340 & 0.040 & 29.92 & 74.87 & 366.5 & 19.2 & 5 \\
\hline HZSM-5 & 575 & 512 & 0.522 & 0.431 & 0.091 & 45.72 & 119.9 & 455.1 & 18.72 & 8 \\
\hline AlMo-ZSM-5 & 408 & 420 & 0.414 & 0.357 & 0.057 & 41.48 & 82.47 & 325.9 & 21.86 & 13 \\
\hline CrMo-ZSM-5 & 390 & 365 & 0.388 & 0.344 & 0.044 & 31.17 & 76.36 & 313.8 & 22.02 & 19 \\
\hline FeMo-ZSM-5 & 424 & 481 & 0.436 & 0.387 & 0.048 & 34.39 & 97.02 & 327.2 & 22.82 & 34 \\
\hline Mord. & 583 & 434 & 0.339 & 0.333 & 0.006 & 14.55 & 71.61 & 511.0 & 14.28 & 38 \\
\hline AlMo-Mord. & 520 & 538 & 0.529 & 0.475 & 0.054 & 37.16 & 145.8 & 374.1 & 22.82 & 28 \\
\hline CrMo-Mord. & 496 & 429 & 0.465 & 0.421 & 0.044 & 29.98 & 114.4 & 382.2 & 21.17 & 29 \\
\hline FeMo-Mord. & 491 & 417 & 0.400 & 0.361 & 0.038 & 27.51 & 84.46 & 406.5 & 18.40 & 45 \\
\hline
\end{tabular}

Figure 4 shows the FTIR spectra of $\mathrm{Al}, \mathrm{Cr}$, and FeMo-Anderson supported on different zeolite samples as well as the spectra of parent zeolites. The spectra presented bands of varying intensity and width are susceptible to the framework structure typical for NaY [24] [25]. The intensity of the characteristic bands of $\mathrm{NaY}$ decreased after supporting the $\mathrm{M}^{3+} \mathrm{Mo}$-Andersone. Another band at 915 $\mathrm{cm}^{-1}$ was observed. Since the IR spectra in the $950-900 \mathrm{~cm}^{-1}$ region become independent of the sort of heteroatom, it can be attributed to the common pattern of Anderson molybdopolyanions [19]. The band at $481 \mathrm{~cm}^{-1}$ is assigned to the structure-insensitive $\mathrm{T}-\mathrm{O}$ bending modes for tetrahedral $\mathrm{TO}_{4}$ units $(\mathrm{T}=\mathrm{Si}$ or $\mathrm{Al}$ ), while the band at $580 \mathrm{~cm}^{-1}$ is associated with the FUA structure [19] [26]. On the other hand, the characteristic bands of ZSM-5 at 452,798 and $1100 \mathrm{~cm}^{-1}$ 

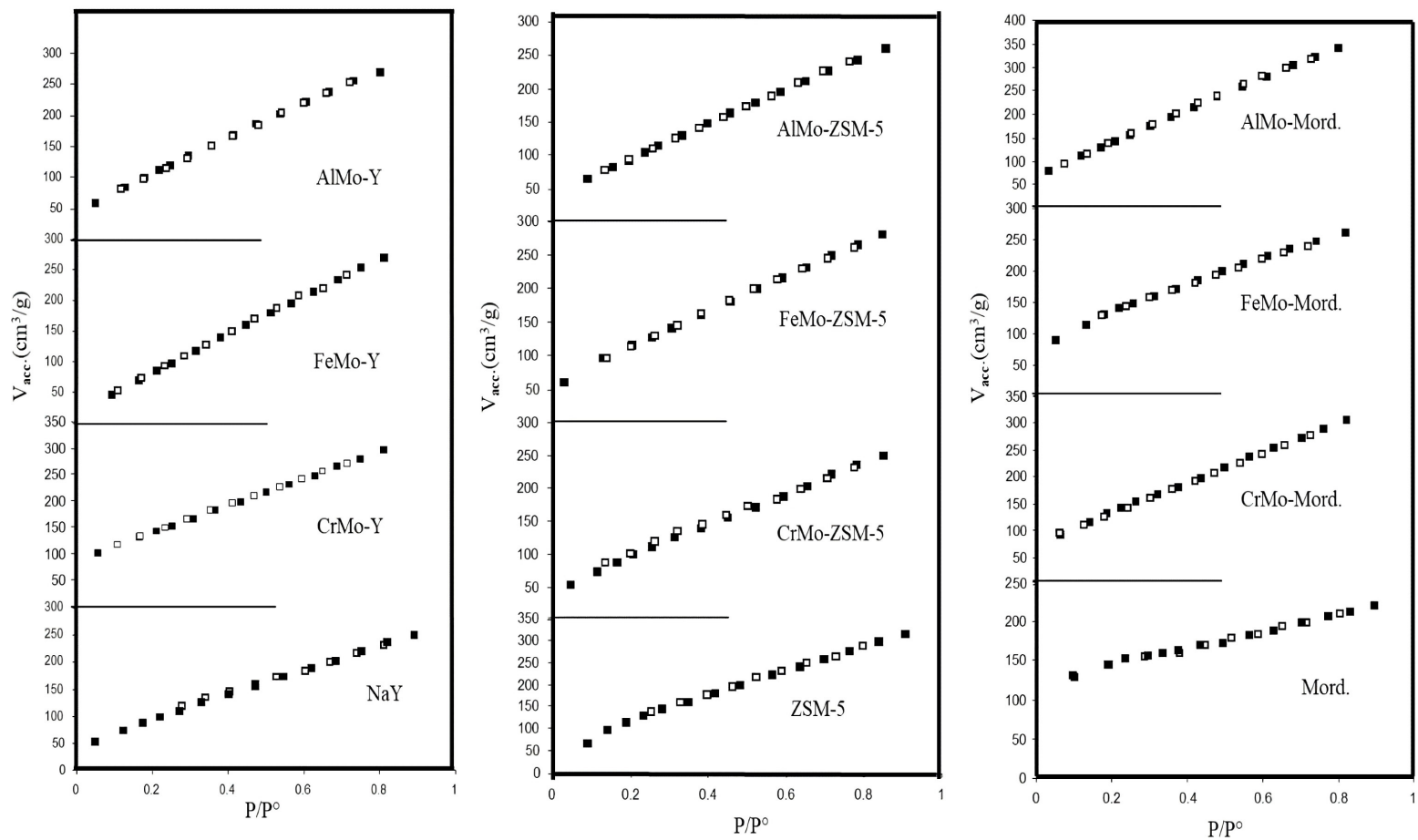

Figure 2. $\mathrm{N}_{2}$ adsorption-desorption isotherms of parent zeolites and $\mathrm{M}^{3+}$ Mo-zeolite solids with different $\mathrm{M}^{3+}$ Mo-Anderson.
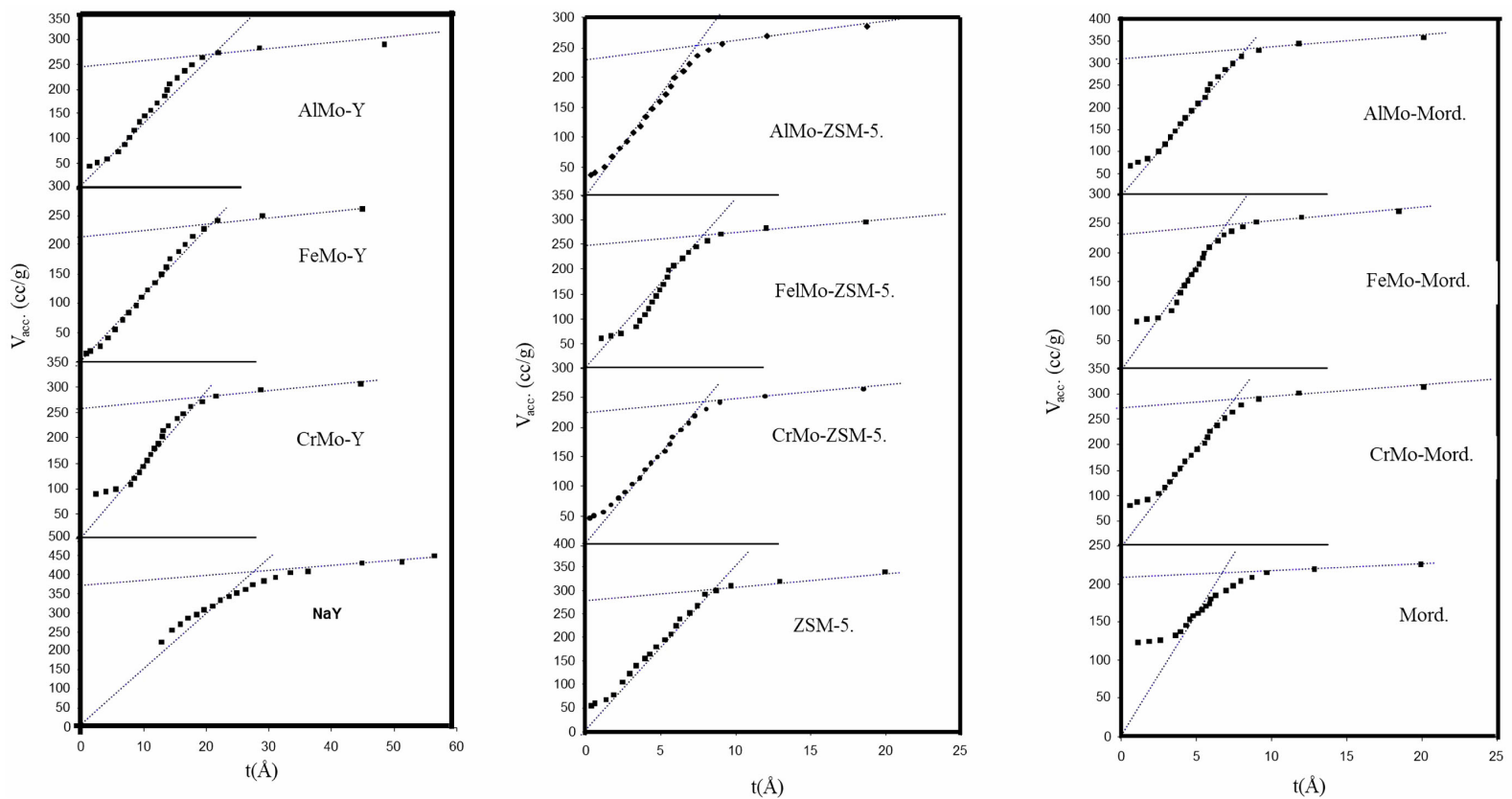

Figure 3. $\mathrm{V}_{1-\mathrm{t}}$ plots of parent zeolites and $\mathrm{M}^{3+}$ Mo-zeolite solids with different $\mathrm{M}^{3+} \mathrm{Mo}$-Anderson.

were detected in the spectra and they are due to the vibration of $\mathrm{SiO}_{4}$ tetrahedra in ZSM-5 framework. Additionally, the vibration at $452 \mathrm{~cm}^{-1}$ was attributed to the five-membered rings in the pentasil structure [27] [28]. Another band at $1226 \mathrm{~cm}^{-1}$ was also observed and may be assigned to $\mathrm{SiO}_{2}$ and $\mathrm{T}-\mathrm{O}$ tetrahedral ( $\mathrm{T}=\mathrm{Si}$ or $\mathrm{Al})$. These data refer to the structure of ZSM-5 is remaining intact as confirmed by XRD results. The change in the spectra is independent of the type 

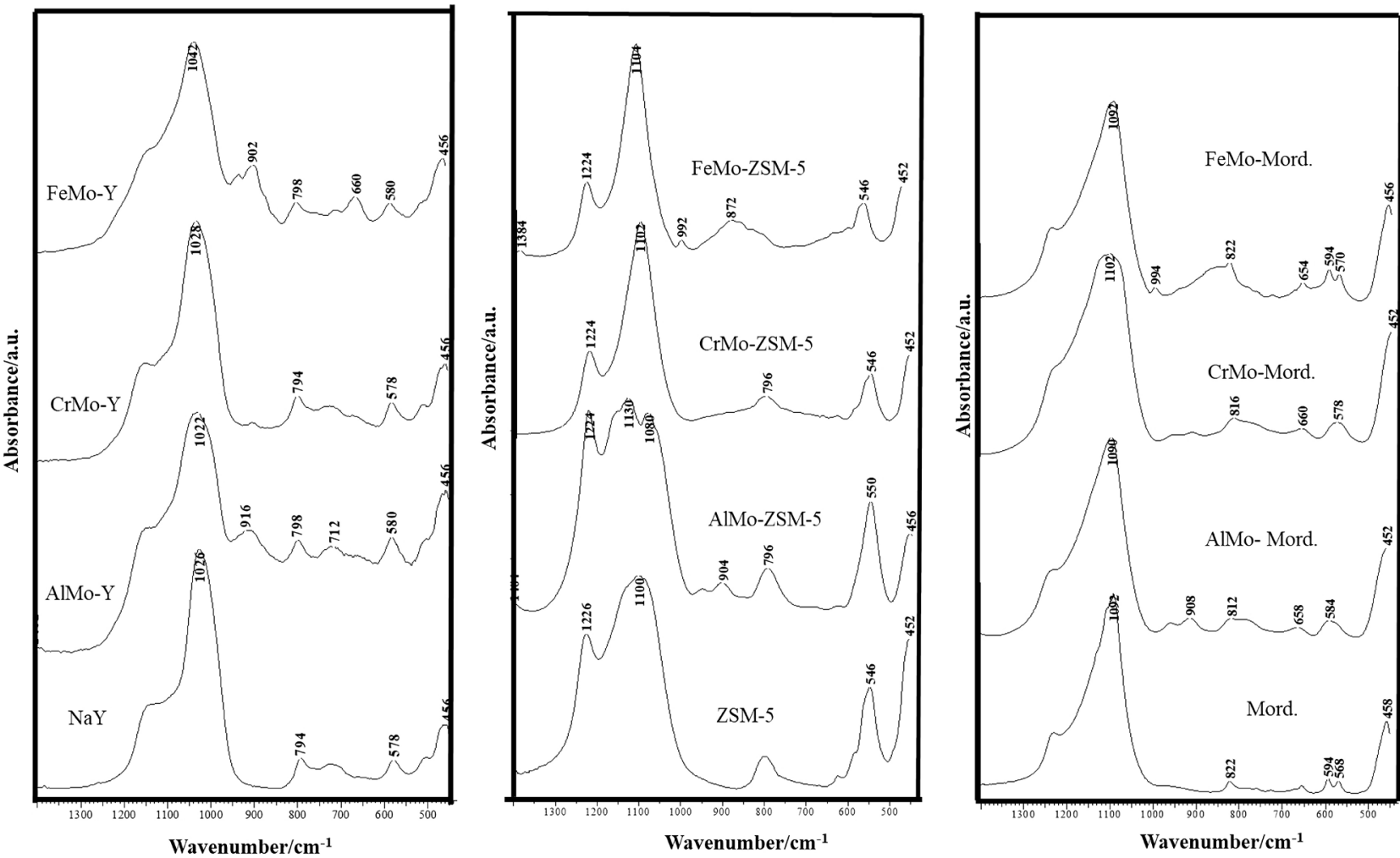

Figure 4. FTIR spectra of parent zeolites and $\mathrm{M}^{3+} \mathrm{Mo}$-zeolite solids with different $\mathrm{M}^{3+} \mathrm{Mo}$-Anderson.

of the heteroatom. The spectra show a new band at $992 \mathrm{~cm}^{-1}$ and it was attributed to the heteropolymolybdate structure. Typical vibrations belonging to mordenite are observed at 1230as, 1092as, $822 \mathrm{~s} \mathrm{~cm}^{-1}$, double ring at 594, 568 $\mathrm{cm}^{-1}$ and finally T-O bending at 653 and $458 \mathrm{~cm}^{-1}$ [29]. Three bands appear at 594 and $653 \mathrm{~cm}^{-1}$. Such bands may be attributed to the frequency of a chain of alternating $\mathrm{TO}_{4}$ in the crystal lattice [30]. The spectra showed a new band around $994 \mathrm{~cm}^{-1}$ and were attributed to the heteropolymolybdate structure since it was observed in the bulk Anderson material.

The solution with initial $\mathrm{pH}$ value 6.4 was used without controlling the $\mathrm{pH}$ value during the catalytic process. Degradation of Direct Blue 1 dye over $\mathrm{M}^{3+} \mathrm{Mo}$-zeolite catalysts enhanced the activity towards the degradation of dye in both cases of the presence and absence of UV irradiation. It is clear from Table 4 and Figure 5 that the catalytic activity depended on both the heteroatom in the Anderson type structure and the type of support. The rate of degradation of dye using $\mathrm{M}^{3+}$ Mo-Anderson supported on ZSM-5 and mordenite is higher than that supported on $\mathrm{NaY}$. A result was explained on the basis that the incorporation of HPA in ZSM-5 and mordenite leads to $20 \%$ reduction of their surface area whereas; the surface area reduction was around $50 \%$ in case of $\mathrm{NaY}$ zeolite. This refers to that HPA is mostly located on the external surface and not in the pores of ZSM-5 and mordenite zeolites. While the Anderson types were mostly incorporated in the pores of NaY zeolite. The degradation efficiency of DB1 dye on the samples was $43 \%$ and $28 \%$ after one min. of reaction time then reached to 

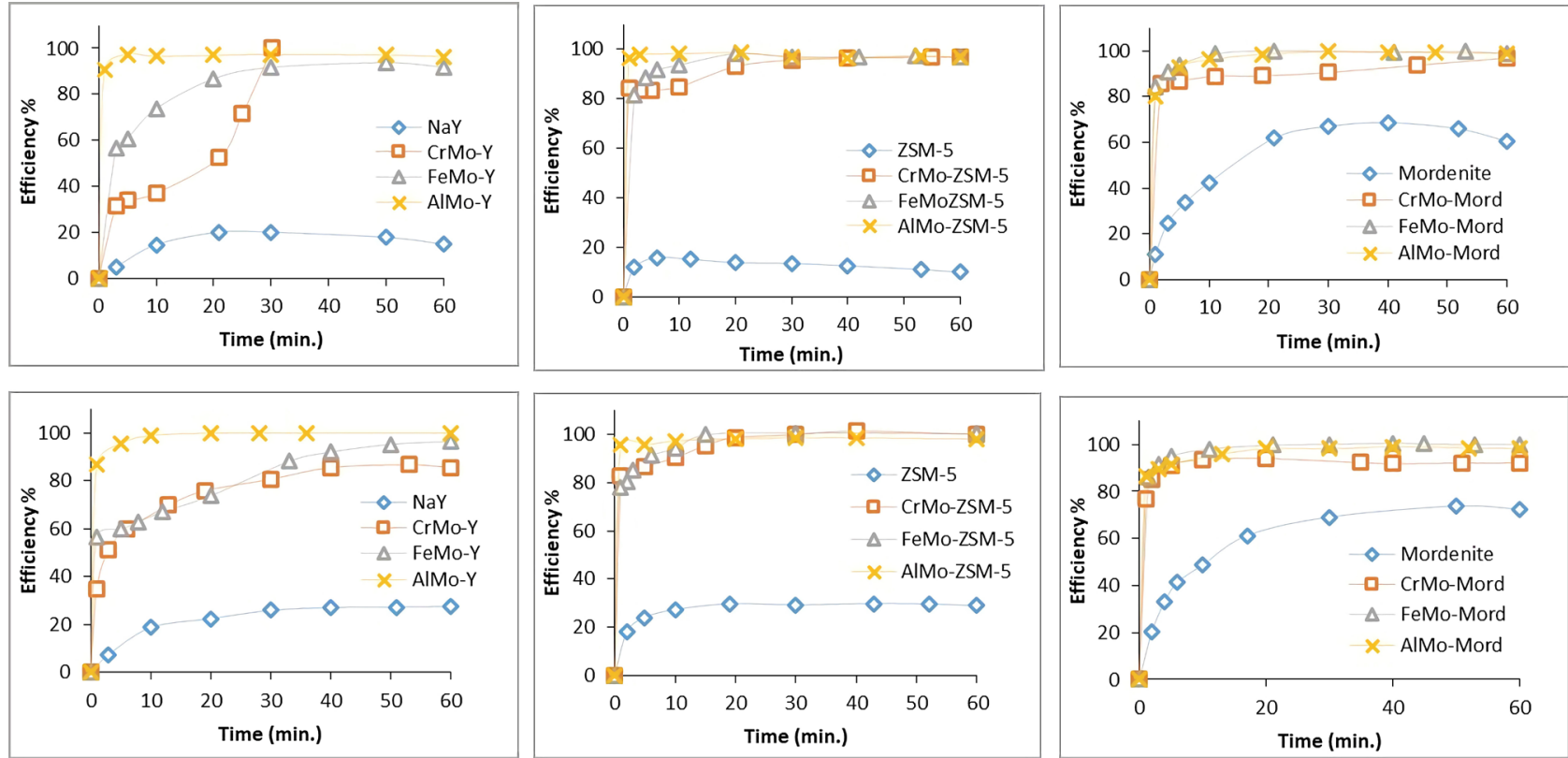

Figure 5. Effect of different Anderson- $\mathrm{M}^{3+} /$ zeolites on degradation of DB1 dye in (a) absence and (b) presence of UV irradiation.

Table 4. Kinetics rate of the dye removal using the catalytic oxidation in the absence and presence of UV irradiation.

\begin{tabular}{ccccccc}
\hline & Sample & $\mathbf{k}, \mathrm{min}^{-1}$ & Sample & $\mathbf{k}, \mathrm{min}^{-1}$ & Sample & $\mathbf{k}, \mathbf{m i n}^{-1}$ \\
\hline \multirow{2}{*}{$\begin{array}{c}\text { Without } \\
\text { irradiation }\end{array}$} & AlMo-Mord & 0.11653 & AlMo-Y & 0.03521 & AlMo-ZSM-5 & 0.08389 \\
& CrMo-Mord. & 0.0509 & CrMo-Y & 0.01295 & CrMo-ZSM-5 & 0.05356 \\
& FeMo-Mord & 0.24055 & FeMo-Y & 0.06461 & FeMo-ZSM-5 & 0.13955 \\
\multirow{2}{*}{$\begin{array}{c}\text { With } \\
\text { irradiation }\end{array}$} & AlMo-Mord & 0.13707 & AlMo-Y & 0.28090 & AlMo-ZSM-5 & 0.10406 \\
& FrMo-Mord. & 0.06011 & CrMo-Y & 0.0384 & CrMo-ZSM-5 & 0.06331 \\
& FeMo-Mord & 0.25507 & FeMo-Y & 0.0725 & FeMo-ZSM-5 & 0.16213 \\
\hline
\end{tabular}

$80 \%$ and $41 \%$ after 15 minutes in absence of UV irradiation, respectively. However, in the presence of UV irradiation over FeMo-Y and CrMo-Y, the degradation efficiency increased to $13 \%$ after one minute, since it was $56 \%$ and $40.5 \%$ after one minute and reached to $92 \%$ and $81 \%$ after 30 minutes, respectively. The observed decrease in $\mathrm{pH}$ from 6.4 to 3 after the mixing of a dye solution with $\mathrm{M}^{\mathrm{n}+}$ Mo-zeolite catalysts may be due to the formation of $\mathrm{M}-\mathrm{O}$ bond results from the coordination combination of dissolved metal ions with water molecules. Furthermore, the dye molecule releases four sulphonate groups which lead to a decrease of $\mathrm{pH}$ value in the reaction course [31] [32].

\section{Conclusion}

The present work comprises the preparation of a trivalent heteropolyacids supported on NaY, ZSM-5 and mordenite zeolites. The $\mathrm{M}^{\mathrm{n}+}$ Mo-zeolite samples have a similar structure to that of parent zeolites with a decrease of the crystallinity and intensities. The formed new phases for $\mathrm{MoO}_{3}, \mathrm{Fe}_{2}\left(\mathrm{MoO}_{3}\right)_{3}$ and $\mathrm{Al}_{2}\left(\mathrm{MoO}_{4}\right)_{3}$ 
that have been shown in XRD were confirmed by FTIR spectra. Some differences in surface texture properties are shown in sample zeolites lowering in surface area, pore widening values as a result of the enforced location of metal oxides in the pores of supported samples, thus, increasing the calculated values of mean pore radii than those of the parent zeolites. The degradation of DB1 dye was slightly higher than in the dark due to the fact that the catalysts have relatively high energy gab. The marked decrease in $\mathrm{pH}$ during the process of the degradation was expected to be due to the interaction among $\mathrm{M}-\mathrm{O}$ and $\mathrm{OH}$ that release hydrogen ions. Furthermore, the ionization of dye sulphonic acid groups also contributes to the $\mathrm{pH}$ drop. On the other hand, it's clear that the modified Y zeolite exhibits the lowest efficiency which might be due to the lowering of surface area following the modification process. The degradation efficiency of DB1 dye was in the range of $28 \%$ - $43 \%$ after one minute of the reaction and reached to $80 \%$ after 15 minutes in absence of UV, while it was $56 \%$ and $40 \%$ after one minute, and then reached to $92 \%$ and $81 \%$ after 30 minutes in presence of UV irradiation.

\section{Conflicts of Interest}

The author declares no conflicts of interest regarding the publication of this paper.

\section{References}

[1] Wang, E.B., Hu, C.W. and Xu, L. (1998) Concise of Polyoxometalate Chemistry. Chemical Industry Press, Beijing.

[2] Boussema, F., et al. (2018) Dawson-Type Polyoxometalate Nanoclusters Confined in a Carbon Nanotube Matrix as Efficient Redox Mediators for Enzymatic Glucose Biofuel Cell Anodes and Glucose Biosensors. Biosensors and Bioelectronics, 109, 20-26. https://doi.org/10.1016/j.bios.2018.02.060

[3] Zhou, L., Wang, L., Cao, Y., Diao, Y., Yan, R. and Zhang, S. (2017) The States and Effects of Copper in Keggin-Type Heteropolyoxometalate Catalysts on Oxidation of Methacrolein to Methacrylic Acid. Molecular Catalysis, 438, 47-54. https://doi.org/10.1016/j.mcat.2017.04.031

[4] Song, Y.-F. and Tsunashima, R. (2012) Recent Advances on Polyoxometalate-Based Molecular and Composite Materials. Chemical Society Reviews, 41, 7384-7402. https://doi.org/10.1039/c2cs35143a

[5] Pope, M.T. and Müller, A. (1991) Polyoxometalate Chemistry: An Old Field with New Dimensions in Several Disciplines. Angewandte Chemie International Edition in English, 30, 34-48. https://doi.org/10.1002/anie.199100341

[6] Katsoulis, D.E. (1998) A Survey of Applications of Polyoxometalates. Chemical Reviews, 98, 359-388. https://doi.org/10.1021/cr960398a

[7] Kozhevnikov, I.V. (1998) Catalysis by Heteropoly Acids and Multicomponent Polyoxometalates in Liquid-Phase Reactions. Chemical Reviews, 98, 171-198. https://doi.org/10.1021/cr960400y

[8] Lü, H., et al. (2017) Synthesis of a Hybrid Anderson-Type Polyoxometalate in Deep Eutectic Solvents (DESs) for Deep Desulphurization of Model Diesel in Ionic Liquids (ILs). Chemical Engineering Journal, 313, 1004-1009. 
https://doi.org/10.1016/j.cej.2016.10.140

[9] Omwoma, S., Gore, C.T., Ji, Y., Hu, C. and Song, Y.-F. (2015) Environmentally Benign Polyoxometalate Materials. Coordination Chemistry Reviews, 286, 17-29. https://doi.org/10.1016/j.ccr.2014.11.013

[10] Carey, J.H. (1992) An Introduction to Advanced Oxidation Processes (AOP) for Destruction of Organics in Wastewater. Water Pollution Research Journal of Canada, 27, 1-22.

[11] Legrini, O., Oliveros, E. and Braun, A.M. (1993) Photochemical Processes for Water Treatment. Chemical Reviews, 93, 671-698. https://doi.org/10.1021/cr00018a003

[12] Wang, S.-S. and Yang, G.-Y. (2015) Recent Advances in Polyoxometalate-Catalyzed Reactions. Chemical Reviews, 115, 4893-4962. https://doi.org/10.1021/cr500390v

[13] Foussard, J.-N., Debellefontaine, H. and Besombes-Vailhe, J. (1989) Efficient Elimination of Organic Liquid Wastes: Wet Air Oxidation. Journal of Environmental Engineering, 115, 367-385. https://doi.org/10.1061/(ASCE)0733-9372(1989)115:2(367)

[14] Pintar, A. and Levec, J. (1992) Catalytic Oxidation of Organics in Aqueous Solutions: I. Kinetics of Phenol Oxidation. Journal of Catalysis, 135, 345-357. https://doi.org/10.1016/0021-9517(92)90038-J

[15] Mantzavinos, D., Hellenbrand, R., Livingston, A.G. and Metcalfe, I.S. (1997) Reaction Mechanisms and Kinetics of Chemical Pretreatment of Bioresistant Organic Molecules by Wet Air Oxidation. Water Science \& Technology, 35, 119-127. https://doi.org/10.2166/wst.1997.0100

[16] Anandan, S., Ryu, S.Y., Cho, W. and Yoon, M. (2003) Heteropolytungstic Acid (H3PW12O40)-Encapsulated into the Titanium-Exchanged HY (TiHY) Zeolite: A Novel Photocatalyst for Photoreduction of Methyl Orange. Journal of Molecular Catalysis A: Chemical, 195, 201-208. https://doi.org/10.1016/S1381-1169(02)00571-X

[17] Dutta, P.K. and Kim, Y. (2003) Photochemical Processes in Zeolites: New Developments. Current Opinion in Solid State \& Materials Science, 7, 483-490. https://doi.org/10.1016/j.cossms.2004.02.004

[18] Dubey, N., Rayalu, S.S., Labhsetwar, N.K., Naidu, R.R., Chatti, R.V. and Devotta, S. (2006) Photocatalytic Properties of Zeolite-Based Materials for the Photoreduction of Methyl Orange. Applied Catalysis A: General, 303, 152-157.

[19] Nomiya, K., Takahashi, T., Shirai, T. and Miwa, M. (1987) Anderson-Type Heteropolyanions of Molybdenum (VI) and Tungsten (VI). Polyhedron, 6, 213-218. https://doi.org/10.1016/S0277-5387(00)80791-3

[20] Scherrer, P. (1918) Estimation of the Size and Internal Structure of Colloidal Particles by Means of Röntgen. Nachrichten von der Gesellschaft der Wissenschaften zu Göttingen, 2, 96-100.

[21] Brunauer, S., Emmett, P.H. and Teller, E. (1938) Adsorption of Gases in Multimolecular Layers. Journal of the American Chemical Society, 60, 309-319. https://doi.org/10.1021/ja01269a023

[22] De Boer, J.H., Linsen, B.G. and Osinga, T.J. (1965) Studies on Pore Systems in Catalysts: VI. The Universal T Curve. Journal of Catalysis, 4, 643-648. https://doi.org/10.1016/0021-9517(65)90263-0

[23] Brunauer, S., Emmett, P.H. and Teller, E. (1938) Adsorption of Gases in Multimolecular Layers. Journal of the American Chemical Society, 60, 309-319. https://doi.org/10.1021/ja01269a023 
[24] Hadjiivanov, K. and Knözinger, H. (1999) FTIR Study of the Low-Temperature Adsorption and Co-Adsorption of $\mathrm{CO}$ and $\mathrm{N}_{2}$ on $\mathrm{NaY}$ Zeolite: Evidence of Simultaneous Coordination of Two Molecules to One $\mathrm{Na}^{+}$Site. Chemical Physics Letters, 303, 513-520. https://doi.org/10.1016/S0009-2614(99)00229-8

[25] Rao, L.F., Fukuoka, A., Kosugi, N., Kuroda, H. and Ichikawa, M. (1990) Characterization of NaY-Entrapped Hexadecacarbonylhexarhodium Cluster by FTIR and EXAFS Spectroscopies and the Catalytic Behavior in Carbon-13 Monoxide Isotopic Exchange Reaction. The Journal of Physical Chemistry, 94, 5317-5327.

https://doi.org/10.1021/j100376a029

[26] Madsen, C., Madsen, C. and Jacobsen, C.J.H. (1999) Nanosized Zeolite Crystals-Convenient Control of Crystal Size Distribution by Confined Space Synthesis. Chemical Communications, 673-674. https://doi.org/10.1039/a901228a

[27] Flanigen, M. and Sand, L.B. (1971) Molecular Sieve Zeolites I. Vol. 101. https://doi.org/10.1021/ba-1971-0102

[28] Zecchina, A., et al. (1996) FTIR Investigation of the Formation of Neutral and Ionic Hydrogen-Bonded Complexes by Interaction of H-ZSM-5 and H-Mordenite with $\mathrm{CH}_{3} \mathrm{CN}$ and $\mathrm{H}_{2} \mathrm{O}$ : Comparison with the H-NAFION Superacidic System. The Journal of Physical Chemistry, 100, 16584-16599. https://doi.org/10.1021/jp960433h

[29] Korkuna, O., Leboda, R., Skubiszewska-Zie, J., Vrublevs'Ka, T., Gun'Ko, V.M. and Ryczkowski, J. (2006) Structural and Physicochemical Properties of Natural Zeolites: Clinoptilolite and Mordenite. Microporous and Mesoporous Materials, 87, 243-254. https://doi.org/10.1016/j.micromeso.2005.08.002

[30] Bevilacqua, M., Alejandre, A.G., Resini, C., Casagrande, M. and Ramirez, J. (2002) An FTIR Study of the Accessibility of the Protonic Sites of H-Mordenites. Physical Chemistry Chemical Physics, 4, 4575-4583. https://doi.org/10.1039/b201886a

[31] Cavani, F. (1998) Heteropolycompound-Based Catalysts: A Blend of Acid and Oxidizing Properties. Catalysis Today, 41, 73-86. https://doi.org/10.1016/S0920-5861(98)00039-X

[32] Chen, Y., Sun, Z., Yang, Y. and Ke, Q. (2001) Heterogeneous Photocatalytic Oxidation of Polyvinyl Alcohol in Water. Journal of Photochemistry and Photobiology A: Chemistry, 142, 85-89. https://doi.org/10.1016/S1010-6030(01)00477-4 